\title{
RELATIONSHIP BETWEEN PARENTING STYLES AND AGGRESSION IN PAKISTANI ADOLESCENTS
}

\section{Ambreen Anjum $^{\bowtie \prime}$, Tayyaba Noor', Noreen Sharif'}

\section{ABSTRACT}

OBJECTIVE: To assess the relationship between parenting styles and aggression in adolescents studying in various schools of Lahore, Pakistan.

METHODS: This cross-sectional study was conducted on 200 adolescents ( 100 male \& 100 females). Parenting Style Questionnaire and Aggression scale were used to collect the data. Sample was selected from 3 schools of Lahore (King Way High School, Shaheen High School and Lahore Garrison School) using purposive sampling strategy. The age range of sample was 14 to 18 years. In the present study we hypothesized; adolescents with authoritarian parents will have high level of aggression as compared to the adolescents of authoritative parents. We used Pearson Correlation and Multiple Regression techniques to find out the results from collected data.

RESULTS: Mean age of participants was $13.09 \pm 0.86$ years. Significant positive association was found between authoritarian parenting style and aggression $(\mathrm{P}<0.0 \mathrm{I})$ and significant inverse relationship between authoritative style of parenting and aggression $(P<0.05)$ in adolescents. So, parents with authoritarian parenting style had higher level of aggression. Authoritarian parenting significantly predicted (19\%) aggression in adolescents, while authoritative parenting style was not a significant predictor of aggression in adolescents.

CONCLUSION: In our study, there is significant effect of authoritative and authoritarian parenting style on aggression and most of the children from authoritarian parents have high level of aggression as compared to authoritative parents.

KEY WORDS: Aggression (MeSH); Adolescents (MeSH); Parenting Style Questionnaire (Non-MeSH); Authoritative (Non-MeSH); Authoritarian (Non$\mathrm{MeSH})$; Aggression scale (Non-MeSH); Parenting (MeSH).

THIS ARTICLE MAY BE CITED AS: Anjum A, Noor T, Sharif N. Relationship between parenting styles and aggression in Pakistani adolescents. Khyber Med Univ J 20I9; I (2):98-I0I. DOI: I0.35845/kmuj.20I9.I8568

\section{INTRODUCTION}

$\mathrm{P}$ arents support and promote the social, emotional, physical, and intellectual development of a child throughout the life span and particularly from infancy to adulthood.' Parenting style is a psychological construct that describe particular strategy parents employ in the brought up of their children. ${ }^{2}$ Parents are different in their style of parenting, i.e. one may be authoritative and the other authoritarian. Both terms look similar but have different characterics. Parents are guardian and that is why term "authoritative" is use for parents. However, authoritative parents have medium level of demand.' They focus on the positive reinforcement of their children. They try to explore hidden abilities of their children. Their focus is to realize the children about the negative and adverse consequences of their actions or mistakes. ${ }^{3}$ Such parents are neither too much strict, nor very lenient. Children of authoritative parents have high self-esteem and learn
I. The Islamia University of Bahawalpur, Bahawalpur, Pakistan.

Email ${ }^{凶}$ : aambreenaanjum@gmail.com

Contact \#: +92-3332755701

Date Submitted:

August 19, 2018

Date Revised:

June 16, 2019

Date Accepted:

June 20, 2019

from their mistakes and grow without any fear of rejection.' So, this is the best parenting style. On the other hand, authoritarian types of parents have high demands from their children. ${ }^{3,4}$ They are very rigid and strict. They impose their strict rules over their children. They have behavioral as well as psychological control of their children.

Numerous researches describe relationship between parent's attitude and psychological well-being. ${ }^{4,5}$ Parents help their children to shape responsible behavior. ${ }^{2}$ Several researches describe that interaction between parent and child is related to child's confidence. Children with caring behavior of parents reported good mental health as compared to parents who were overprotective for their children. ${ }^{6,7}$ People with damaged self-worth have a greater risk of developing social and psychological problems. ${ }^{4}$

Aggression is a behavioral problem that causes to harm themselves or other people. ${ }^{8}$ Aggressive behavior may be direct or indirect. ${ }^{7}$ In a direct aggression one may harm physically or verbally and indirect aggression involve behavior intended to impair one's social relations. In recent years, aggression appear as one of the gravest social ills in Pakistani society. According to the findings of several researches parenting style is positively related to aggression. ${ }^{2}$ There is well documented evidence that authoritarian parenting leads to aggression and behavioral problems in adoloscents. 'If adolescents exposed to strict behavior and rules, they might begin to employ such strict and harsh behaviors in their interactions with family and peer. ${ }^{8}$ So, parent's discipline strategies play important role in the development of children behavior.

Although, parenting style and aggression has been studied in western 
TABLE I: CHARACTERICS OF STUDY PARTICIPANTS $(n=200)$

\begin{tabular}{|l|c|c|c|}
\hline Variables & Category & Frequency & Percentage \\
\hline \multirow{3}{*}{ Gender } & Male & 100 & 50 \\
\cline { 2 - 4 } & Female & 100 & 50 \\
\hline \multirow{3}{*}{ Age (years) } & 14 & 46 & 23 \\
\cline { 2 - 4 } & 15 & 50 & 25 \\
\cline { 2 - 4 } & 16 & 52 & 26 \\
\cline { 2 - 4 } & 17 & 52 & 26 \\
\hline \multirow{3}{*}{ Class } & $8^{\text {th }}$ & 60 & 30 \\
\cline { 2 - 4 } & $9^{\text {th }}$ & 68 & 34 \\
\cline { 2 - 4 } & $10^{\text {th }}$ & 72 & 36 \\
\hline
\end{tabular}

TABLE II: DESCRIPTIVE STATISTICS OF AUTHORITATIVE, AUTHORITARIAN AND AGGRESSION SCALE

\begin{tabular}{|l|c|c|c|c|c|}
\hline Variables & K & Means & SD & $\boldsymbol{\alpha}$ & Min-Max Score \\
\hline Authoritative & 15 & 38.19 & 6.22 & .84 & $15-75$ \\
\hline Authoritarian & 12 & 36.03 & 8.90 & .70 & $12-60$ \\
\hline Aggression & 29 & 79.01 & 12.05 & .89 & $29-145$ \\
\hline
\end{tabular}

$\mathrm{K}=$ number of questions in scale, $\alpha=$ Cronbach's alpha, Min $=$ minimum score, Max $=$ maximum score

TABLE III: RELATIONSHIP BETWEEN AUTHORITARIAN, AUTHORITATIVE PARTING STYLE AND AGGRESSION IN ADOLESCENTS

\begin{tabular}{|l|c|c|c|}
\hline Variables & I & $\mathbf{2}$ & $\mathbf{3}$ \\
\hline Authoritarian & - & .11 & $.40^{*} *$ \\
\hline Authoritative & - & - & -.09 \\
\hline Aggression & - & - & - \\
\hline Mean & 36.03 & 38.19 & 79.01 \\
\hline SD & 8.90 & 6.22 & 12.05 \\
\hline
\end{tabular}

TABLE IV: MULTIPLE REGRESSION ANALYSIS FOR PREDICTING AGGRESSION IN ADOLESCENTS

\begin{tabular}{|l|c|c|c|c|c|c|}
\hline Variables & B & SEB & B & t & p-value & 95\% CL (LL-UL) \\
\hline Constant & 6.91 & 3.52 & & & & \\
\hline Authoritarian & .88 & .14 & .42 & 6.53 & .000 & $.62-1.15$ \\
\hline Authoritative & -.31 & .13 & -.14 & -2.28 & .02 & $-.57-.04$ \\
\hline
\end{tabular}

countries, limited studies are available on parenting style in Asian context particularly in Pakistan. This study explored the effect of both authoritative and authoritarian parenting styles on aggression in adolescents. The main objective of present study was to explore which one of the parenting styles predicts aggression in adolescents. The findings of the present study will be helpful for parents, children and practitioners.

\section{METHODS}

In the present study, cross-sectional research design was employed. The objective of this study was to find out the effect of parenting style on aggression in adolescents. The data of present study was collected from 3 schools (King Way High School, Shaheen High School and Lahore Garrison School) during January 2017 to October 2017. These schools were selected randomly after compiling a list of high schools of Lahore city. Study participants (200) with the age range of 14 to 18 years were included in this study using purposive sampling technique. Of these potential participants, 60 were from class $8^{\text {th }}, 68$ from $9^{\text {th }}$ and 72 from $10^{\text {th }}$. Only those adolescents were selected who were willing to participate in the study. Participants with prior history of any clinical problem were excluded from the study. Data was collected with the help of demographic information sheet including quarries regarding gender, age and education. Parenting Styles Questionnaire $^{10}$ was used to assess styles of parenting. This scale consisted of 27 items. Parenting Styles Questionnaire is previously used and validated in the indigenous studies." Twenty nine items Buss Perry aggression scale ${ }^{12}$ was used to assess level of aggression in adolescents. This scale is also previously used and validated in indigenous researches. ${ }^{13}$

The present study was approved by the research committee of Punjab University of Lahore. Data was collected after the written permission of school authorities. Written informed consent was also obtained from parents of selected children with the help of school teachers. We collected all the data in class rooms. Data was collected personally and all assumptions were checked before further analysis.

SPSS version 22.0 was used for data analysis. Frequency and percentages were calculated for gender, age and academic class. Pearson correlation was used to find out relationship between parenting styles and aggression. Multiple regression analysis was used to predict aggression in adolescents of authoritative and authoritarian parents.

\section{RESULTS}

In the present study a total of 200 participants were selected from both the public and private schools. Mean age of participants was $13.09 \pm 0.86$ year. Demographic details of study participants are given in Table $\mathrm{l}$.

Table II indicated that the alpha coefficients of all scales of present study are reliable to find out the responses of our study participants.

Table III showed significant positive relationship between authoritarian parenting style and aggression (0.40**). Further findings indicated that negative relationship between parenting authoritative style and aggression.

Table IV results indicated that authoritarian parenting significantly predicts aggression and this explained 
$19 \%$ variance with $F(2,197)=22.52$, $\mathrm{p}<0.0 \mathrm{l}$. Whereas, authoritative parenting style is not significant predictor of aggression in adolescents.

\section{DISCUSSION}

Findings of present study revealed authoritarian parenting style is a significant predictor of aggression. Our findings are in accord with results of western empirical studies on this particular phenomenon. ${ }^{2,12}$ Researchers describe that children with authoritarian parenting style develop anger and harsh attitude with family and peers as compared to children with authoritative paring style. ${ }^{14}$ Some other supportive research work conducted in Pakistan amplifies that children with authoritarian parenting style have elevated level of aggression."

Now a days, psychologists and professionals recommend and encourage parents, family members and teachers that try to modify their focus more on child's' individual values of development for example selfrespect, confidence, and independence rather than strict academic performance. ${ }^{15}$ Parenting with authoritative style provides warm attitude that help in developing a child as socially responsible and acceptable among peers.

Furthermore, participants of this study are emerging adulthood. This is the unique developmental transition phase from adolescence to adulthood. Studies described the influence of parenting styles on aggression and attitude in between the period of late adolescence and young adulthood. During emerging adulthood, parenting style that young adults received at either their younger time or present plays critical role in their adjustment. Young adult who had exposure of positive parenting style showed significantly associated to their positive temperament. On the other hand, findings of several studies have mentioned that young adults from authoritarian families tend to have high level of aggression, lesser creativity and capability. ${ }^{16}$

\section{CONCLUSION}

Results of this study showed that authoritarian parenting style practiced by the majority of parents in Pakistan. Besides these results, findings also showed that there is significant effect of authoritative and authoritarian parenting style on aggression and most of the children from authoritarian parents have high level of aggression as compared to authoritative parents.

\section{LIMITATIONS}

Sample of this study was selected from schools of one city. In order to generalize sample should be large and from other cities as well. Another constraint of this study was access of limited information regarding this issue.

\section{REFERENCES}

I. Carlo G, Knight GP, Mcginley M, Hayes R. The roles of parental inductions, moral emotions, and moral cognitions in prosocial tendencies among Mexican American and European American early adolescents. J Early Adolesc 20II;3I(6):757-8I. DOI: I0.II77/ 0272431610373100 .

2. Grusec JE. Socialization processes in the family: social and emotional development. Annu Rev Psychol 2011;62: 243-69. DOI: 10.1146/ annurev.psych. I 21208.131650 .

3. Abar CC, Jackson KM, Wood M. Reciprocal relations between perceived parental knowledge and adolescent substance use and delinquency: the moderating role of parent-teen relationship quality. Dev Psychol 2014;50(9): 2176-87. DOI: 10.1037/a0037463.

4. Rothrauff TC, Cooney TM, An JS. Remembered parenting styles and adjustment in middle and late adulthood. J Gerontol B Psychol Sci Soc Sci 2009;64(I):137-46. DOI: 10.1093/geronb/gbn008.

5. Martikainen P, Bartley M, Lahelma E. Psychosocial Determinants of Health in Social Epidemiology. Int J Epidemiol 2002; 3I(6): I09I-3. DOI: 10.1093/ije/31.6.1091.
6. Caprara GV, Pastorelli C. Early emotional instability, prosocial behavior, and aggression: some methodological aspects. Eur J Pers 1993;7(1):19-36. DOI: 10.1002/ per.24l0070103.

7. Carlo G, Mcginley M, Hayes R, Batenhorst C, Wilkinson J. Parenting styles or practices? Parenting, sympathy, and prosocial behaviors among adolescents. J Genet Psychol 2007; I68(2): I47-76. DOI: 10.3200/GNTP.168.2.147176.

8. Carlo G, Mestre MV, Samper P, Tur A, Armenta BE. Feelings or cognitions? Moral cognitions and emotions as longitudinal predictors of prosocial and aggressive behaviors. Pers Individ Dif 2010;48(8):872-7. DOI: 10.1016/ j.paid.2010.02.010

9. Darling N, Steinberg L. Parenting style as context: an integrative model. Psychol Bull 1993;113(3) :487-96. DOI: 10.1037/ 00332909.113.3.487

10. Robinson C, Mandleco B, Olsen F, Hart C. Authoritative, authoritarian, and permissive parenting practices: development of a new measure. Psychol Rep 1995;77(3):819-30. DOI: 10.2466/pr0.1995.77.3.819

II. Saleem S, Sana D, Zahid M. Perceived parenting styles in Pakistani adolescents: A validation study. Pak Psychol Res 2017;32(2): 487-509.

12. Buss AH, Perry MP. The aggression questionnaire. J Pers Soc Psychol 1992;63(3):452-9. DOI: 10.1037/ 0022-35|4.63.3.452.

13. Kokeb A, Munaf S, Khan B. Relationship of perceived parental behavior at the stage of adolescent with life satisfaction and aggression of adult daughters. Bahria J Profes Psychol 2014; I3(2): I- 16.

14. Steinberg L. We know some things: parent-adolescent relationships in retrospect and prospect. J Res Adolesc 200I;II(I):I-19. DOI: I0.1||I//532-7795.0000I.

15. Steinberg L, Lamborn SD, Darling N, Mounts NS, Dornbusch SM. 
Over-time changes in adjustment and competence among adolescents from authoritative, authoritarian, indulgent, and neglectful families. Child Dev
1994;65(3):754-70. DOI: 10.1III/ j.I467-8624.1994. tb0078I.x.

16. Archer J. Sex differences in aggression in real- world settings: $A$ meta-analytic review. Rev Gen Psychol 2004;8(4):29I-322. DOI: |0.1037/1089-2680.8.4.29|

\section{AUTHORS' CONTRIBUTIONS}

Following authors have made substantial contributions to the manuscript as under:

AA: Concept and study design, analysis and interpretation of data, drafting the manuscript, final approval of the version to be published

TN: Acquisition, analysis and interpretation of data, critical review, final approval of the version to be published

NS: Acquisition of data, critical review, final approval of the version to be published

Authors agree to be accountable for all aspects of the work in ensuring that questions related to the accuracy or integrity of any part of the work are appropriately investigated and resolved.

\section{CONFLICT OF INTEREST}

Authors declared no conflict of interest GRANT SUPPORT AND FINANCIAL DISCLOSURE

NIL

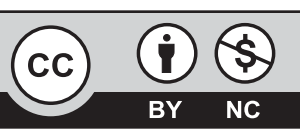

This is an Open Access article distributed under the terms of the Creative Commons Attribution-Non Commercial 2.0 Generic License.
KMUJ web address: www.kmuj.kmu.edu.pk

Email address: kmuj@kmu.edu.pk 